\title{
,and \\ Optimization of Heat Treatment Parameters of AlSi7Mg Alloy
}

\author{
Jacek Pezda
}

check for

updates

Citation: Pezda, J. Optimization of

Heat Treatment Parameters of AlSi7Mg Alloy. Materials 2022, 15 ,

1163. https://doi.org/10.3390/

ma15031163

Academic Editor: Chao Xu

Received: 13 December 2021

Accepted: 29 January 2022

Published: 2 February 2022

Publisher's Note: MDPI stays neutral with regard to jurisdictional claims in published maps and institutional affiliations.

Copyright: (C) 2022 by the author. Licensee MDPI, Basel, Switzerland. This article is an open access article distributed under the terms and conditions of the Creative Commons Attribution (CC BY) license (https:/ / creativecommons.org/licenses/by/ $4.0 /)$.
Department of Manufacturing Technology and Automation, University of Bielsko-Biala, 43-309 Bielsko-Biała, Poland; jpezda@ath.bielsko.pl

\begin{abstract}
Constantly growing requirements concerning the quality of poured machinery components give rise to the need to find new solutions to improve their mechanical and technological properties, considering economic and ecological aspects resulting from energy consumption of the casting and heat treatment processes. This study presents the investigation of the effect of heat treatment on mechanical properties (tensile strength $R_{m}$, elongation $A_{5}$, hardness $H B W$ ) of the AlSi7Mg alloy without modification and modified with strontium. Obtained results allowed us to determine T6 heat treatment parameters associated with the improvement of mechanical properties of the alloy with simultaneous limitation of duration of solutioning and aging treatments. The maximum increase in $R_{m}$ was $67 \%$, and $55 \%$ in the case of $H B W$, with a slight decrease in elongation (approx. $10 \%$ ) in relation to an alloy not subjected to heat treatment in the adopted scope of tests for the total time of heat treatment of $4-6 \mathrm{~h}$. The increase in elongation of up to $250 \%$ requires aging at a temperature exceeding $300{ }^{\circ} \mathrm{C}$, which also causes a decrease in durability and hardness by $20 \%$. Modification of the alloy using strontium before heat treatment facilitates the process of fragmentation and balling of silicone precipitates.
\end{abstract}

Keywords: Al-Si alloy; mechanical properties; heat treatment

\section{Introduction}

The alloys belonging to the Al-Si group, due to their parameters, are widely used in the aviation and automotive industries. However, very often, they require improvement of their mechanical properties due to high operational requirements for heavily loaded components that must feature a high degree of reliability. An effective method of hardening materials, enabling considerable improvement of their mechanical properties, uses the phenomena of decreasing solubility of alloying elements in the solid-state as the limit temperature decreases [1-4]. The treatment to which the material is subjected consists of two stages. During the first one (solutioning), the alloy is heated at a temperature above the limit of solubility in the area of a single-phase solid solution and then is rapidly cooled down. During the second one (aging), precipitation of the supersaturating component in the form of finely dispersed precipitates occurs. In the case of alloys containing $\mathrm{Cu}$ or $\mathrm{Mg}$, the hardening occurs due to the precipitation of $\mathrm{Al}_{2} \mathrm{Cu} \mathrm{Mg} \mathrm{Mg}_{2} \mathrm{Si}$ and $\mathrm{Al}_{2} \mathrm{CuMg}$ phases [1,5-8].

The treatment used to heat castings in the process of solutioning not only increases the concentration of the elements that are a potential source of precipitation processes in $\alpha$-Al solid solution but can also cause a favorable change in the morphology of eutectic crystals of silicon-their coalescence and spheroidizing. This improves the mechanical properties of silumins. The form of the eutectics during the heat treatment has a significant effect on the susceptibility of eutectic silicon to coalescence and rounding. The phenomena of coalescence and rounding of the eutectic silicon occur more easily and faster when the particles of eutectic silicon are more dispersed prior to the heat treatment, thus enabling shortened time of heat treatment of the alloy $[1,5]$. To this end, modifications in a furnace are performed, where micro-additives (modifiers), which impact the morphology of silicon, are added to the liquid alloy. The most commonly used modifiers include $\mathrm{Na}, \mathrm{Sr}, \mathrm{Ca}$, and $\mathrm{Sb}[5,9-12]$. Additives of these elements cause changes in the growth of phase $\beta$ 
(silicon) of the eutectic, which starts to show a more refined morphology, changing its shape from acicular or lamellar to fibrous. Strontium belongs to elements causing a permanent modification of silumins. Strontium is used mainly to modify hypo- and near eutectic alloys, although, according to certain studies [13-16], its addition brings about positive results also in the case of hyper eutectic alloys, allowing for complex modifications of Si precipitations. In most cases, strontium is inserted into liquid metal in the form of Al-Sr master alloys, containing up to $10 \% \mathrm{wt}$. of $\mathrm{Sr}$, and prepared in the form of ingots or extruded rods. The structure of Al-Si eutectics obtained after correct modification is characterized, not only by a minimum interphase distance of the eutectics, but also by rounding of contours and bigger fraction of dendrites of plastic $\alpha$-Al phase compared to an unmodified alloy, which is characterized by large dendrites of $\alpha$-Al phase and lamellar silicon, which look like needles (when viewed in two dimensions). The modifying effect of strontium is analogous to the impact of correct modification using sodium. Moreover, Sr neutralizes the effect of phosphorus and makes the structure of eutectics more fibrous [6,17-20]. Such a change in the morphology translates into an essential improvement of mechanical properties, in particular ductility, and facilitates the processes of coalescence and coagulation of silicon in the course of heat treatment. In practice, Sr is added within the limits of $0.04-0.07 \%$ of the mass of the metallic charge [12].

The duration and temperature of solutioning, suitable cooling, and artificial aging [4,21-23] have a direct impact on the improvement of mechanical properties in terms of heat treatment. The ASTM B917-01 standard provides the saturation time of $6-12 \mathrm{~h}$ at $540{ }^{\circ} \mathrm{C}$ for 356.0 alloys, cooling in warm water, and then $2-5 \mathrm{~h}$ of aging at $155^{\circ} \mathrm{C}$, for sand mold castings [24], while in case of metal molds it provides $4-12 \mathrm{~h}$ of saturation at $540^{\circ} \mathrm{C}$ and $2-5 \mathrm{~h}$ of aging at $15^{\circ} \mathrm{C}$ [24]. On the other hand, AFS proposes saturation at $538^{\circ} \mathrm{C}$ for $12 \mathrm{~h}$ and aging at $155^{\circ} \mathrm{C}$ for $3-5 \mathrm{~h}$ for casting to sand molds, and $227^{\circ} \mathrm{C}$ for chill casting molds [25]. Ambient temperature aging processes occurring between quenching and artificial aging (natural aging) should be minimized as they reduce the precipitation driving force necessary for artificial aging [26].

The cost and time of such a type of treatment are of fundamental importance, and the reduction of parameters of the T6 heat treatment process has a beneficial effect on manufacturing costs and productivity [4,27-29]. Many authors have carried out studies aimed to determine the effects of parameters of solutioning and aging treatments on mechanical properties and the microstructure of cast AlSi7Mg alloy [30-32]. In this area, there are quite large discrepancies in the temperature range and the time of solutioning and aging operations to ensure the required improvement of the mechanical properties of the casting.

The objective of this study was to evaluate the parameters of T6 heat treatment for unmodified and modified AlSi7Mg alloy, taking into account the possibility of improving its mechanical properties, including limitation of the time of the heat treatment with reduction of energy consumption and improved productivity of the process in mind.

\section{Materials and Methods}

Because of its good technological and casting properties, the analyzed alloy is used to manufacture castings for the automotive and machine-building industries. This alloy is poured into sand molds and metal molds and obtains a strength of up to $350 \mathrm{MPa}$ [33-38] and up to $400 \mathrm{MPa}$ when fabricated by selective laser melting [39].

In the next step, the studied alloy, featuring the chemical composition presented in Table 1, was melted and refined (Rafal 1, 0.6\% mass of metallic charge at the temperature of $730{ }^{\circ} \mathrm{C}$ ). After refining, the modification was treated via the addition of a modifier in the form of AlSr10 master alloy in the quantity of $0.6 \%$ mass of the metallic charge to the bath.

Then, the mold intended for the production of test pieces was filled with refined and modified alloy. The mold was produced in compliance with the PN-88/H-88002 standard [40]. The output cast cylindrical test piece had a diameter of $16 \mathrm{~mm}$ and a length of $160 \mathrm{~mm}$. 
Table 1. Chemical composition of EN AC-AlSi7Mg alloy, wt. \%.

\begin{tabular}{cccccccccc}
\hline $\mathbf{S i}$ & $\mathbf{F e}$ & $\mathbf{C u}$ & $\mathbf{M n}$ & $\mathbf{M g}$ & $\mathbf{C r}$ & $\mathbf{N i}$ & $\mathbf{Z n}$ & $\mathbf{T i}$ & $\mathbf{A l}$ \\
\hline 7.5 & 0.6 & 0.25 & 0.2 & 0.3 & 0.07 & 0.1 & 0.3 & 0.04 & balance \\
\hline
\end{tabular}

The heat treatment was performed for unmodified and modified alloy. T6 heat treatment consisted of solutioning heating, followed directly by cooling in cold water $\left(20^{\circ} \mathrm{C}\right)$, and then artificial aging followed by cooling in the open air.

Figure 1 presents temperature ranges of the solutioning and aging operations as implemented in the course of performed treatments, applied on curves from the DTA method.

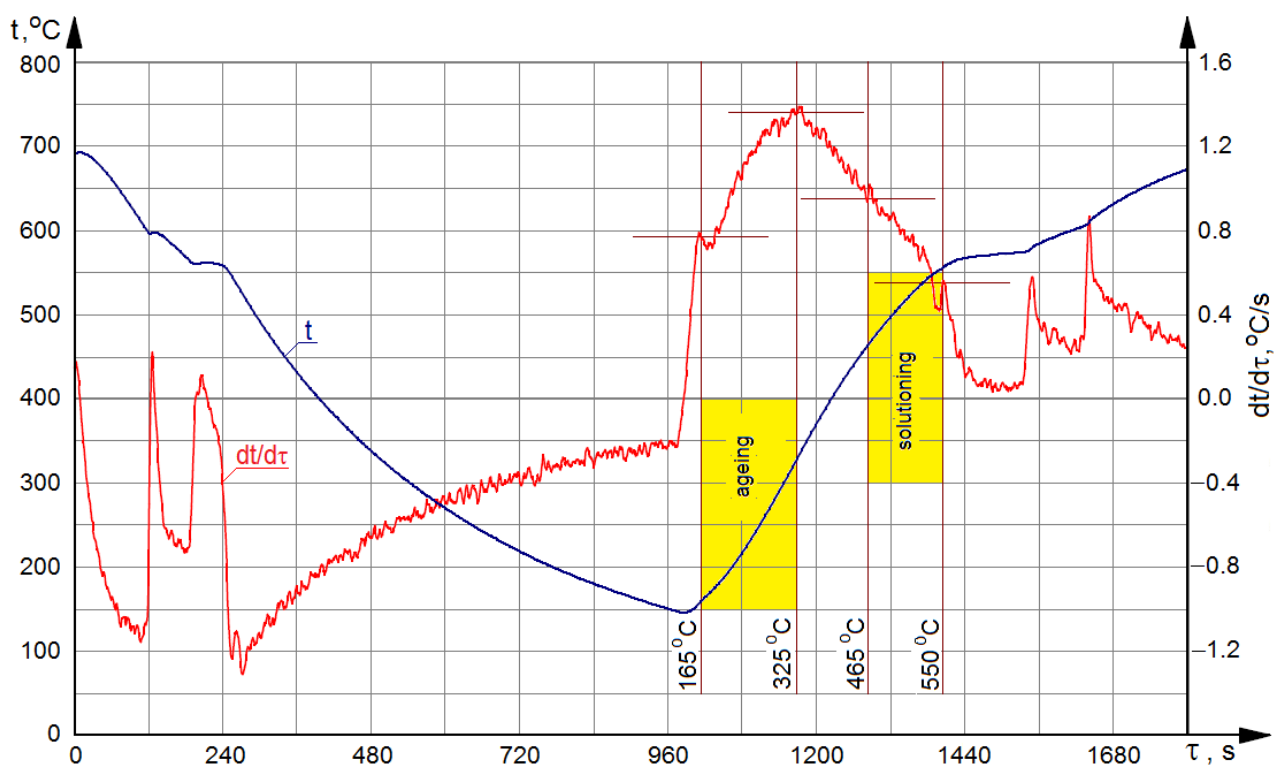

Figure 1. Curves from the DTA method for crystallization and melting of the modified AlSi7Mg alloy.

The heat treatment of the tested alloy was performed based on a trivalent plan of the testing with four variables (Table 2). For each system from the testing plan, the process was repeated three times, i.e., three test pieces of unmodified alloy and three test pieces of modified alloy were cast and heat treated. Statistic calculations were carried out using Statistica software, version 13.3, developed by StatSoft.

Table 2. The test piece heat treatment plan.

\begin{tabular}{|c|c|c|c|c|}
\hline \multicolumn{2}{|c|}{ Solution Treatment } & \multicolumn{2}{|c|}{ Artificial Aging } & \multirow{2}{*}{ Combination No } \\
\hline Temperature $\left(t_{s}\right),{ }^{\circ} \mathrm{C}$ & Time $\left(\tau_{s}\right), \mathrm{h}$ & Temperature $\left(t_{a}\right),{ }^{\circ} \mathrm{C}$ & Time $\left(\tau_{a}\right), \mathrm{h}$ & \\
\hline \multirow{9}{*}{465} & \multirow{3}{*}{0.5} & 165 & 2 & 1 \\
\hline & & 235 & 8 & 2 \\
\hline & & 325 & 5 & 3 \\
\hline & \multirow{3}{*}{1.5} & 165 & 8 & 4 \\
\hline & & 235 & 5 & 5 \\
\hline & & 325 & 2 & 6 \\
\hline & \multirow{3}{*}{3} & 165 & 5 & 7 \\
\hline & & 235 & 2 & 8 \\
\hline & & 325 & 8 & 9 \\
\hline
\end{tabular}


Table 2. Cont.

\begin{tabular}{|c|c|c|c|c|}
\hline \multicolumn{2}{|c|}{ Solution Treatment } & \multicolumn{2}{|c|}{ Artificial Aging } & \multirow{2}{*}{ Combination No } \\
\hline Temperature $\left(t_{s}\right),{ }^{\circ} \mathrm{C}$ & Time $\left(\tau_{s}\right), \mathrm{h}$ & Temperature $\left(t_{a}\right),{ }^{\circ} \mathrm{C}$ & Time $\left(\tau_{a}\right), \mathrm{h}$ & \\
\hline \multirow{9}{*}{520} & \multirow{3}{*}{0.5} & 165 & 8 & 10 \\
\hline & & 235 & 5 & 11 \\
\hline & & 325 & 2 & 12 \\
\hline & \multirow{3}{*}{1.5} & 165 & 5 & 13 \\
\hline & & 235 & 2 & 14 \\
\hline & & 325 & 8 & 15 \\
\hline & \multirow{3}{*}{3} & 165 & 2 & 16 \\
\hline & & 235 & 8 & 17 \\
\hline & & 325 & 5 & 18 \\
\hline \multirow{9}{*}{550} & \multirow{3}{*}{0.5} & 165 & 5 & 19 \\
\hline & & 235 & 2 & 20 \\
\hline & & 325 & 8 & 21 \\
\hline & \multirow{3}{*}{1.5} & 165 & 2 & 22 \\
\hline & & 235 & 8 & 23 \\
\hline & & 325 & 5 & 24 \\
\hline & \multirow{3}{*}{3} & 165 & 8 & 25 \\
\hline & & 235 & 5 & 26 \\
\hline & & 325 & 2 & 27 \\
\hline
\end{tabular}

Solutioning and aging (at temperatures exceeding $300^{\circ} \mathrm{C}$ ) were performed on the testbed; the scheme of the testbed is presented in Figure 2. A resistance furnace constituted the main part of the testbed. To measure the temperature, a type $\mathrm{K}$ thermocouple was used, which provided a measuring accuracy at the level of $\pm 5^{\circ} \mathrm{C}$. The thermocouple was inserted into the furnace chamber (allowing measurement of the temperature inside the furnace). The measurement of temperature was carried out simultaneously and continuously. Aging at temperatures below $300{ }^{\circ} \mathrm{C}$ was performed in a laboratory dryer of SLN 53 STD type.

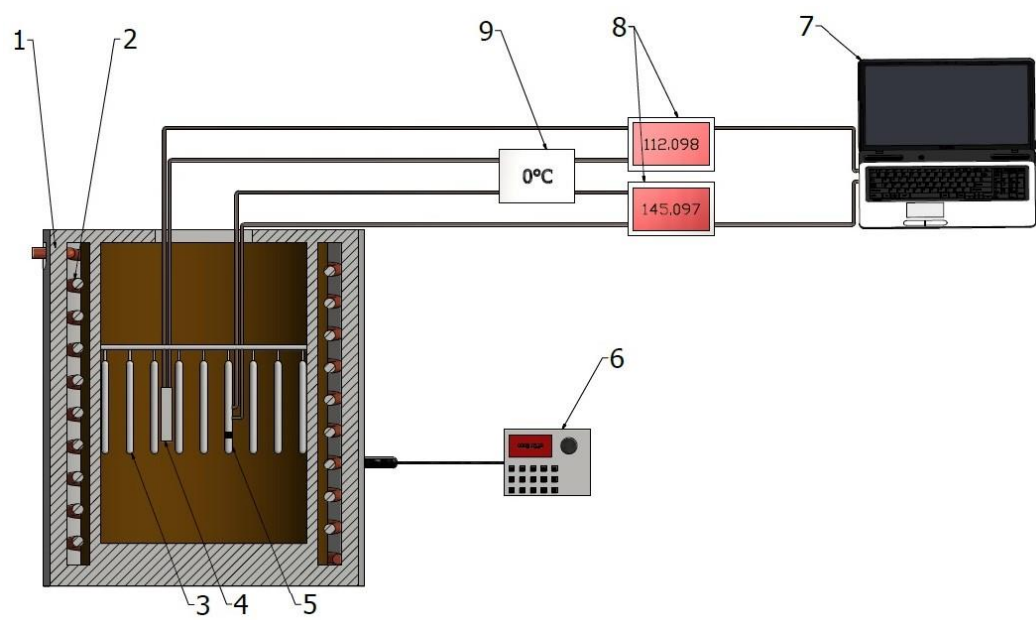

Figure 2. The scheme of the test stand for solution treatment operation (1-electric resistance furnace, 2-heating coil, 3-samples, 4-thermocouple to control furnace's chamber temperature, 5-thermocouple to control temperature of control sample, 6-furnace control, 7-computer to register the furnace chamber and control sample temperatures (measurement every $15 \mathrm{~s}$ ), 8-microvoltmeters (accuracy $\pm 0.01 \mathrm{mV}$ ), 9-reference thermocouple (kept at $0{ }^{\circ} \mathrm{C}$ ). 
The test pieces of the diameter of $10 \mathrm{~mm}$ and the measured length of $50 \mathrm{~mm}$, subjected to static tensile strength, were prepared according to ISO 6892-1:2016 standard [41]. The tensile strength test was performed using the Instron 33R4467 tester. The hardness measurement was carried out based on ISO 6506-1:2014 standard [42], using a ball of $10 \mathrm{~mm}$ diameter at a load of $9800 \mathrm{~N}$ sustained for $30 \mathrm{~s}$. The hardness was measured in the area of milled surfaces of the grasping parts of the test pieces.

The metallographic tests were performed using a Neophot 32 microscope and the "Multiscan" computerized image analysis system.

\section{Results and Discussion}

\subsection{Tensile Strength $R_{m}$ of the Tested Alloy}

Raw alloy (without heat treatment) was characterized by tensile strength $R_{m}$ at the level $190 \mathrm{MPa}$. The refining resulted in the growth of the strength to $195 \mathrm{MPa}$, while the modification made it possible to obtain a value of $200 \mathrm{MPa}$. The performed heat treatment resulted in a change of the tensile strength $R_{m}$ from 154 to $328 \mathrm{MPa}$ for an unmodified alloy and from 154 to $335 \mathrm{MPa}$ for a modified alloy. Taking into account the results obtained in the assumed scope of the tests for the refined and modified alloy before and after the heat treatment, a considerable increase in strength $R_{m}$ (Figure 3) was obtained for the systems from the testing plan denominated as: no. $25\left(t_{s}=550{ }^{\circ} \mathrm{C} ; \tau_{s}=3 \mathrm{~h} ; t_{a}=165{ }^{\circ} \mathrm{C} ; \tau_{a}=8 \mathrm{~h}\right)$, no. $13\left(t_{s}=520{ }^{\circ} \mathrm{C} ; \tau_{s}=1.5 \mathrm{~h} ; t_{a}=165{ }^{\circ} \mathrm{C} ; \tau_{a}=5 \mathrm{~h}\right)$ and no. $19\left(t_{s}=550{ }^{\circ} \mathrm{C} ; \tau_{s}=0.5 \mathrm{~h}\right.$; $\left.t_{a}=165{ }^{\circ} \mathrm{C} ; \tau_{a}=5 \mathrm{~h}\right)$. A similar strength at the level $300 \mathrm{MPa}$ was recorded for systems no. $4,10,16$, which is typical for a low aging temperature $\left(165^{\circ} \mathrm{C}\right)$. On the other hand, the lowest tensile strength $R_{m}$ was obtained for the temperature of aging $\mathrm{t}_{\mathrm{a}}=325^{\circ} \mathrm{C}$ (systems no. 3,9 , and 27).

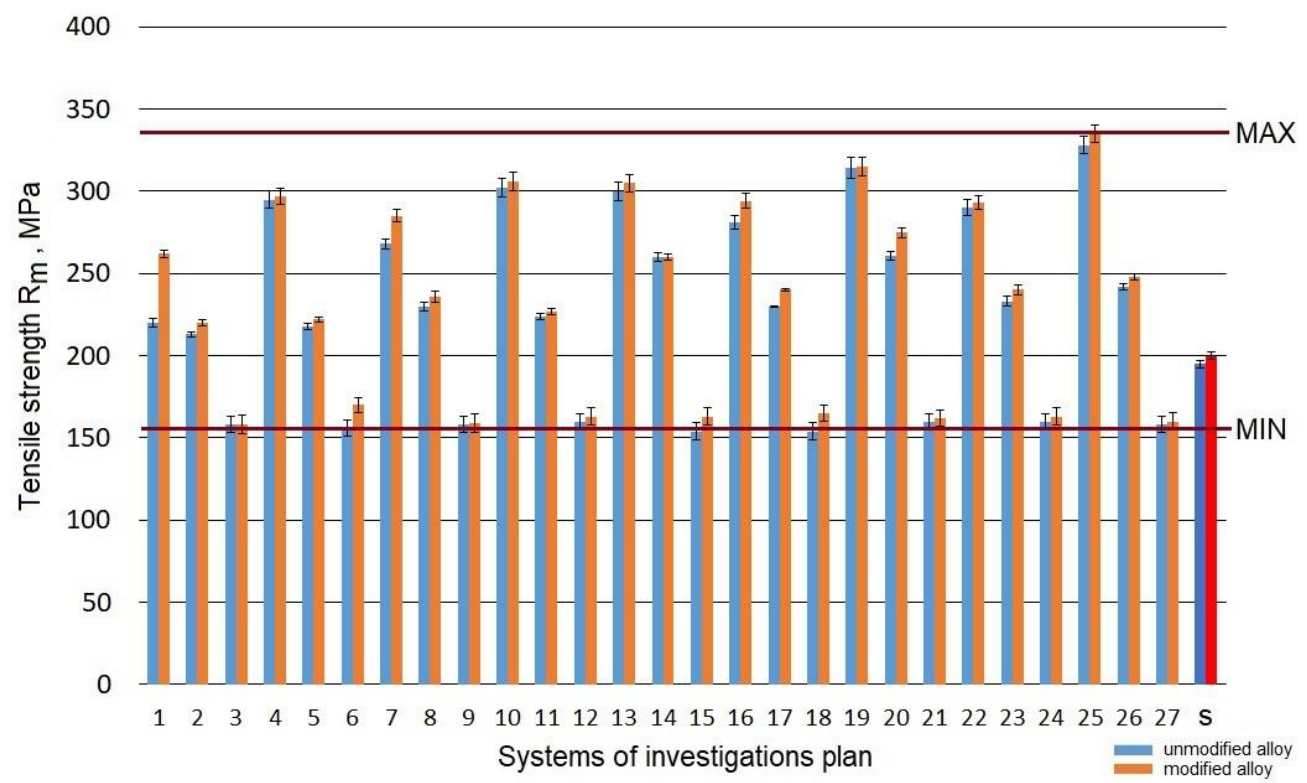

Figure 3. Tensile strength $R_{m}$ of the studied alloy: $s$ - the initial state.

The effect of the heat treatment operations' parameters on the change of tensile strength $R_{m}$ of the modified alloy is depicted by spatial diagrams (Figure 4 ). The spatial diagrams were prepared based on a regression equation in the form of the second-degree polynomial, which takes the form of the relation (1). The equation significance is $\alpha=0.05$.

$$
\begin{aligned}
R_{m}=-64.66+ & 0.738 t_{s}+2.53 \cdot 10^{-4} t_{s}^{2}+60.855 \tau_{s}-0.844 \tau_{s}^{2}+0.655 t_{a} \\
& -2.41 \cdot 10^{-4} t_{a}^{2}+7.64 \tau_{a}+0.364 \tau_{a}^{2}-0.105 t_{s} \tau_{s}-22.68 \\
& \cdot 10^{-4} t_{s} t_{a}-0.007 t_{s} \tau_{a}-0.027 \tau_{s} t_{a}+0.805 \tau_{s} \tau_{a}-0.036 t_{a} \tau_{a}
\end{aligned}
$$


where: $t_{p}$-solutioning temperature, $\tau_{p}$-solutioning time, $t_{s}$-aging temperature, $\tau_{p}$ aging time. Correlation coefficients: $\mathrm{R}^{2}=0.98$; corrr. $\mathrm{R}^{2}=0.96$.

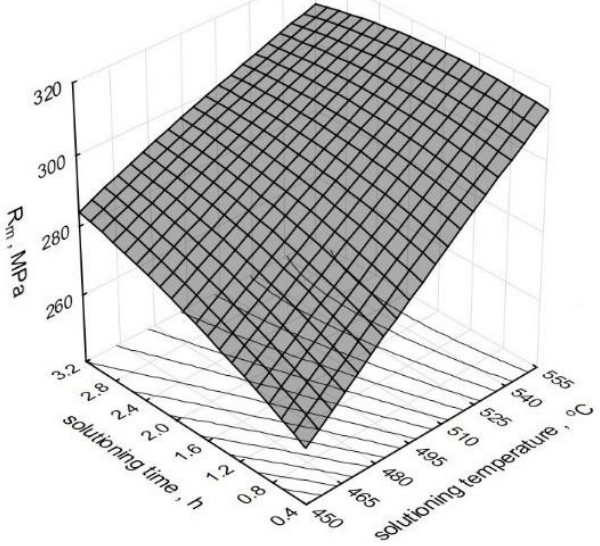

(a)

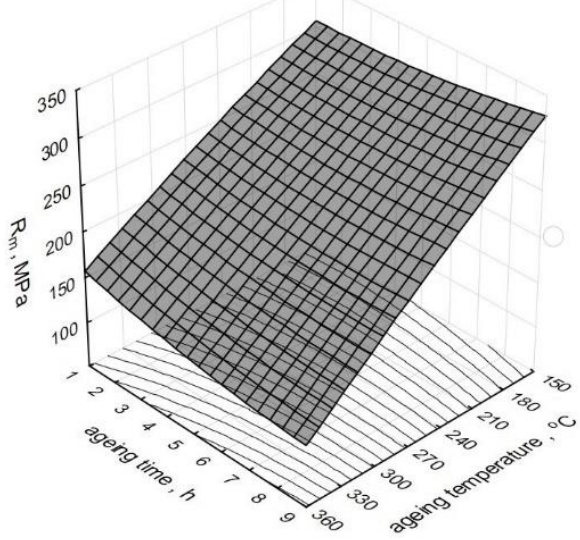

(b)

Figure 4. Effect of T6 heat treatment parameters on the tensile strength $R_{m}$ of the tested alloy: (a) $t_{s}$ and $\tau_{s} ;(\mathbf{b}) t_{a}$ and $\tau_{a}$.

For the unmodified alloy, the dependency (1) takes the form (2):

$$
\begin{aligned}
R_{m}=-573.6+ & 1.7 t_{s}-0.1 \cdot 10^{-4} t_{s}^{2}+111.08 \tau_{s}-2.904 \tau_{s}^{2}+1.648 t_{a}+5.15 \\
& \cdot 10^{-4} t_{a}^{2}+37.74 \tau_{a}+0.008 \tau_{a}^{2}-0.166 t_{s} \tau_{s}-36.4 \cdot 10^{-4} t_{s} t_{a} \\
& -0.047 t_{s} \tau_{a}-0.051 \tau_{s} t_{a}-0.388 \tau_{s} \tau_{a}-0.053 t_{a} \tau_{a}
\end{aligned}
$$

Correlation coefficients: $\mathrm{R}^{2}=0.97$; corr. $\mathrm{R}^{2}=0.95$.

As constant values for the solutioning, we assumed time of $\tau_{s}=1 \mathrm{~h}$ and temperature of $t_{s}=520^{\circ} \mathrm{C}$, while in case of the aging: time of $\tau_{a}=5 \mathrm{~h}$ and temperature of $t_{a}=165{ }^{\circ} \mathrm{C}$.

Solutioning the alloy for 1 to $2 \mathrm{~h}$ at temperature $\mathrm{t}_{\mathrm{s}}=540-550{ }^{\circ} \mathrm{C}$ and aging it at temperature $t_{a}=165^{\circ} \mathrm{C}$ for 5 to $8 \mathrm{~h}$ causes a significant increase in the tensile strength $R_{m}$. By solutioning the alloy modified at the temperature of $540{ }^{\circ} \mathrm{C}$ for $1 \mathrm{~h}$ and aging it at the temperature of $180{ }^{\circ} \mathrm{C}$ for one and four hours, Moller et al. [43] obtained $R_{m}=303 \mathrm{MPa}$, while the further increase obtained at the level of $10 \%$ resulted from the content of $\mathrm{Mg}$ in the alloy increased to $0.4 \%$. By solutioning the alloy at the same temperature for one hour longer and by aging it at $170{ }^{\circ} \mathrm{C}$ for $7 \mathrm{~h}$, the authors of the study [44] obtained the strength of $306 \mathrm{MPa}$ with an addition of $0.5 \% \mathrm{Ti}$. The authors of the study [45] obtained a similar strength $(328 \mathrm{MPa})$ after solutioning at $535^{\circ} \mathrm{C}$ for $6 \mathrm{~h}$ and aging at $160{ }^{\circ} \mathrm{C}$ for $8 \mathrm{~h}$ at the initial value $R_{m}$ of the untreated alloy at the level of $252 \mathrm{MPa}$, i.e., approximately $25 \%$ greater compared to the presented test results. Pedersen [46] obtained the maximum strength at $60 \mathrm{~min}$ of solutioning at $540{ }^{\circ} \mathrm{C}$ and $4 \mathrm{~h}$ of aging at $150{ }^{\circ} \mathrm{C}$, and the longer time of treatment did not increase the strength. Ragab et al. [47] obtained UTS at the level exceeding $300 \mathrm{MPa}$ for an unmodified alloy and a modified alloy after solutioning at $535{ }^{\circ} \mathrm{C}$ for $5 \mathrm{~h}$ and aging after $24 \mathrm{~h}$ at $170{ }^{\circ} \mathrm{C}$ for 4,8 , and $12 \mathrm{~h}$.

According to Shivkumar [48], solutioning for 3-6 h at the temperature of $540{ }^{\circ} \mathrm{C}$ is optimal for a modified alloy cast to sand molds. In his study, Zhang [49], after 30 min of solutioning at the temperature of $540{ }^{\circ} \mathrm{C}$ and $550{ }^{\circ} \mathrm{C}$, obtained more than $90 \%$ of $\mathrm{R}_{0.2}$ value and more than $95 \%$ of $R_{m}$ was obtained using standard solutioning for $6 \mathrm{~h}$. Peng [50] achieved similar mechanical properties, however, after solutioning at $550{ }^{\circ} \mathrm{C}$ for $2 \mathrm{~h}$ and aging at $170{ }^{\circ} \mathrm{C}$, also for $2 \mathrm{~h}$. Reduction of the aging time below $5 \mathrm{~h}$, assuming the aging temperature below $180{ }^{\circ} \mathrm{C}$ is maintained, should provide strength at the level of $300 \mathrm{MPa}$ (Figure 3) and 90-95\% of $R_{m}$ value obtained for aging exceeding $5 \mathrm{~h}$, as in the case of work [50], where reduction of the aging time from 15 to $2 \mathrm{~h}$ decreased the tensile strength by merely $8 \mathrm{MPa}$. 


\subsection{Elongation $A_{5}$ of the Tested Alloy}

The raw alloy (without the heat treatment) was characterized by elongation $A_{5}$ at the level of $5.8 \%$ in the case of the refined alloy and $6.5 \%$ in the case of the modified alloy. The performed heat treatment resulted in a change of the elongation, which was included within the range of $3.7-15.6 \%$ (Figure 5).

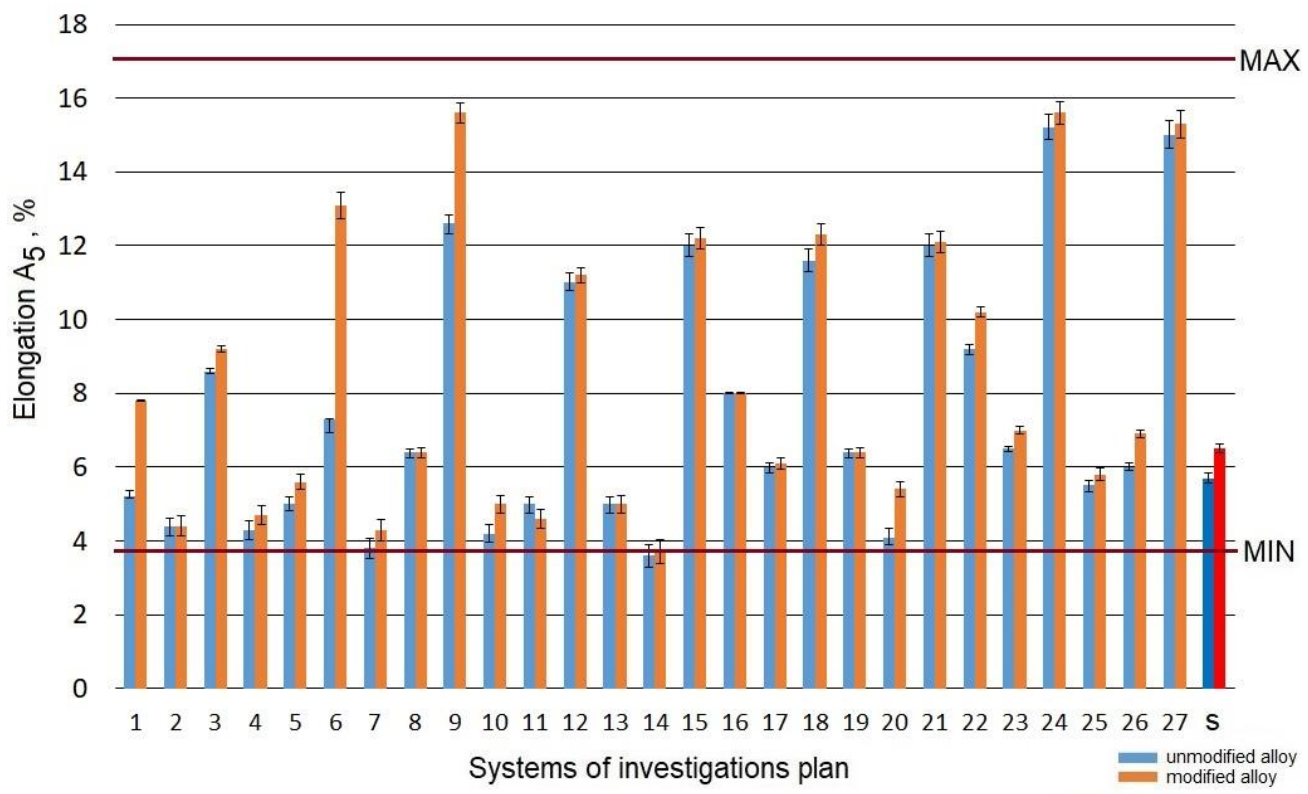

Figure 5. Elongation $A_{5}$ of the studied alloy: s-the initial state.

Considering the results obtained in the assumed area of the testing plan for refined and modified alloy before and after the heat treatment, the elongation $A_{5}$ increased in the case of systems no. $9\left(t_{s}=465{ }^{\circ} \mathrm{C} ; \tau_{s}=0.5 \mathrm{~h} ; t_{a}=325{ }^{\circ} \mathrm{C} ; \tau_{a}=8 \mathrm{~h}\right)$, no. $24\left(t_{s}=550{ }^{\circ} \mathrm{C}\right.$; $\left.\tau_{s}=1.5 \mathrm{~h} ; t_{a}=325{ }^{\circ} \mathrm{C} ; \tau_{a}=5 \mathrm{~h}\right)$, and no. $24\left(t_{s}=550{ }^{\circ} \mathrm{C} ; \tau_{s}=1.5 \mathrm{~h} ; t_{a}=325^{\circ} \mathrm{C} ; \tau_{a}=5 \mathrm{~h}\right)$. A high aging temperature $\left(325^{\circ} \mathrm{C}\right)$ results in an increase in elongation of the alloy, with a simultaneous decrease in its strength. This is due to over-aging of the alloy and results from the loss of coherence of the phase precipitated with the alloy's matrix, as well as coagulation of particles of eutectic silicon.

Aging at low temperature $\left(t_{a}=165^{\circ} \mathrm{C}\right)$ for $5-8 \mathrm{~h}$ causes a decrease in the elongation $A_{5}$ (systems no. $4,7,10$, and 14) compared to the alloy not subjected to heat treatment, both modified and unmodified, by 10-20\%. This results directly from the hardening of the alloy with small precipitates of $\mathrm{Mg}_{2} \mathrm{Si}$ particles inside $\alpha$-Al grains [51]. In addition, reduction of the elongation of the alloy after heat treatment is caused by the direct effect of coarsening of Si particles after T6 temper [52] and is more influenced by the cracking mechanism acting within the material [53].

The effect of parameters of the heat treatment operations on the change of the elongation $A_{5}$ of the modified alloy is depicted by spatial diagrams (Figure 6). The spatial diagrams were prepared based on a regression equation in the form of the second-degree polynomial, which takes the form of the relation (3). The equation significance is $\alpha=0.05$.

$$
\begin{aligned}
A_{5}=234.75- & 0.789 t_{s}+7.94 \cdot 10^{-4} t_{s}^{2}-1.43 \tau_{s}-0.382 \tau_{s}^{2}+0.269 t_{a}+5.83 \\
& \cdot 10^{-4} t_{a}^{2}-2.1 \tau_{a}-0.087 \tau_{a}^{2}+0.002 t_{s} \tau_{s}-0.17 \cdot 10^{-4} t_{s} t_{a} \\
& +0.003 t_{s} \tau_{a}+0.009 \tau_{s} t_{a}+0.012 \tau_{s} \tau_{a}+0.003 t_{a} \tau_{a}
\end{aligned}
$$

where: $t_{p}$ - solutioning temperature, $\tau_{p}$-solutioning time, $t_{s}$-aging temperature, $\tau_{p}$-aging time. Correlation coefficients: $R^{2}=0.97$; corrr. $R^{2}=0.94$. 


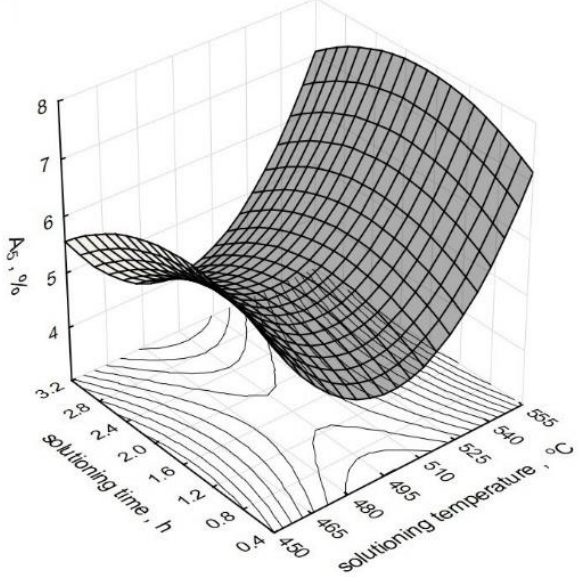

(a)

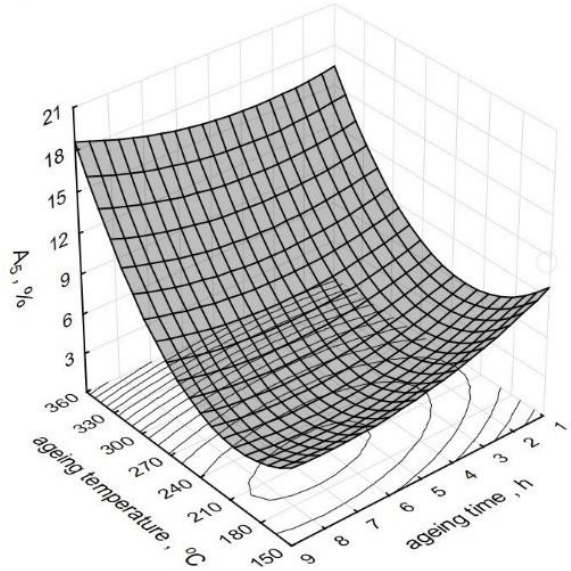

(b)

Figure 6. Effect of T6 heat treatment parameters on elongation $A_{5}$ of the studied alloy: (a) $t_{s}$ and $\tau_{s}$, (b) $t_{a}$ and $\tau_{a}$.

For the unmodified alloy, the dependency (3) takes the form (4):

$$
\begin{aligned}
A_{5}=110.12- & 0.331 t_{s}+3.43 \cdot 10^{-4} t_{s}^{2}-2.13 \tau_{s}-0.163 \tau_{s}^{2}-0.271 t_{a}+4.8 \\
& \cdot 10^{-4} t_{a}^{2}+0.282 \tau_{a}+0.043 \tau_{a}^{2}-0.005 t_{s} \tau_{s}+0.85 \cdot 10^{-4} t_{s} t_{a} \\
& -0.003 t_{s} \tau_{a}+0.005 \tau_{s} t_{a}-0.117 \tau_{s} \tau_{a}-0.004 t_{a} \tau_{a}
\end{aligned}
$$

Correlation coefficients: $\mathrm{R}^{2}=0.9$; corr. $\mathrm{R}^{2}=0.79$.

As constant values for solutioning, we assumed time $\tau_{s}=1 \mathrm{~h}$ and temperature $t_{s}=520{ }^{\circ} \mathrm{C}$, while in case of aging: time $\tau_{a}=5 \mathrm{~h}$ and temperature $t_{a}=165{ }^{\circ} \mathrm{C}$.

Obtaining the maximum increase in the elongation $A_{5}$ of the alloy is preconditioned by its aging at a temperature above $300{ }^{\circ} \mathrm{C}$ for $5-8 \mathrm{~h}$ after previous solutioning for $30-90 \mathrm{~min}$ at the temperature of $520-550{ }^{\circ} \mathrm{C}$. Considering the fact that the temperatures of aging treatment of the AlSi7Mg alloy practically do not exceed $200{ }^{\circ} \mathrm{C}$ (in most cases, they fluctuate between $150-180^{\circ} \mathrm{C}$ ), the obtained elongation was at the level of $6-7 \%$. A similar value of the elongation (7\%) was obtained by Liu [45] after $6 \mathrm{~h}$ of solutioning at $535{ }^{\circ} \mathrm{C}$ and $2 \mathrm{~h}$ of aging at $180^{\circ} \mathrm{C}$. Twice as long aging time at the temperature of $520^{\circ} \mathrm{C}$ and $8 \mathrm{~h}$ of aging at $160{ }^{\circ} \mathrm{C}$ enabled Zyska [54] to achieve $8 \%$ elongation for the unmodified alloy and even $11 \%$ for the alloy subjected to modification. Elongation at the level $5.3 \%$ required $8 \mathrm{~h}$ of solutioning at $530^{\circ} \mathrm{C}$ and $6 \mathrm{~h}$ of aging at $180{ }^{\circ} \mathrm{C}$, while in the case of the author of the paper [32], after solutioning of the alloy at $530^{\circ} \mathrm{C}$ for 8 and $5 \mathrm{~h}$. Three hours shorter time of solutioning at the same temperature and aging at $170{ }^{\circ} \mathrm{C}$ for $1-8 \mathrm{~h}$ allowed to obtain elongation of a modified alloy between 4.2 and 5\% [47]. Much lower elongation (3\%) after reduction of solutioning time to $2 \mathrm{~h}$ and $2 \mathrm{~h}$ of aging at $170{ }^{\circ} \mathrm{C}$ is reported by the author of the paper [55]. An increase in solutioning temperature to $540{ }^{\circ} \mathrm{C}$ resulted in a decrease in elongation within the limit of $10 \%$, same as in the case of the paper [31], where $4 \mathrm{~h}$ of solutioning at this temperature and $6 \mathrm{~h}$ of aging at $160{ }^{\circ} \mathrm{C}$ resulted in $3.2 \%$ elongation for metal mold and 1\% for the casting from a sand mold. Much higher elongation, i.e., 5\%, for an unmodified alloy and 7\% for a modified alloy, was obtained by Wang [52] after solutioning at the same temperature for $12 \mathrm{~h}$ and aging at $155{ }^{\circ} \mathrm{C}$ for $10 \mathrm{~h}$. The use of the same solutioning temperature allowed another author [30] to obtain $8.7 \%$ elongation after $6 \mathrm{~h}$ of solutioning and $4 \mathrm{~h}$ of aging at $155^{\circ} \mathrm{C}$. Lu [28] limited the solutioning time to $30 \mathrm{~min}$ (aging for $90 \mathrm{~min}$ at $180{ }^{\circ} \mathrm{C}$ ); the result accounted for $90 \%$ of the elongation value observed in the case of $10 \mathrm{~h}$ of solutioning at the same temperature and $5 \mathrm{~h}$ of aging at $170{ }^{\circ} \mathrm{C}$. Similarly, Zhang [56], for a low-pressure casting, obtained $95 \%$ of the maximum elongation after solutioning for $6 \mathrm{~h}$ at $540{ }^{\circ} \mathrm{C}$. However, Peng achieved $80 \%$ of the maximum elongation (7\%) obtained after solutioning at $535^{\circ} \mathrm{C}$ for $4 \mathrm{~h}$ and aging at $170{ }^{\circ} \mathrm{C}$ for $15 \mathrm{~h}$ [50] after $2 \mathrm{~h}$ 
of solutioning at $550{ }^{\circ} \mathrm{C}$ and aging at $170{ }^{\circ} \mathrm{C}$. Taking into accout the elongation after heat treatment of modified and unmodified alloys, it should be ascertained that modification has a positive effect on elongation of the untreated alloy [54,57] due to refining of silicon precipitates and that it facilitates their spheroidization during T6 treatment [58]. Moreover, spheroidization of silicon precipitates results in the growth of fracture toughness and ductility $[59,60]$. Taking into account the high hardness and low ductility of the precipitates of eutectic silicon, the growth of their size causes a reduction in the fracture stress of A356 alloys. At the same time, the decrease in the ultimate tensile strength and a slight increase in ductility can be noticed [61].

\subsection{Hardness HBW10/1000/30 of the Tested Alloy}

As-cast alloy (without heat treatment) featured hardness at the level of $58 \mathrm{HBW10/1000/30}$ for modified alloy and $60 \mathrm{HBW} 10 / 1000 / 30$ for unmodified alloy. Heat treatment operations changed the hardness of the alloy within the range of 41-101 HBW10/1000/30 (Figure 7).

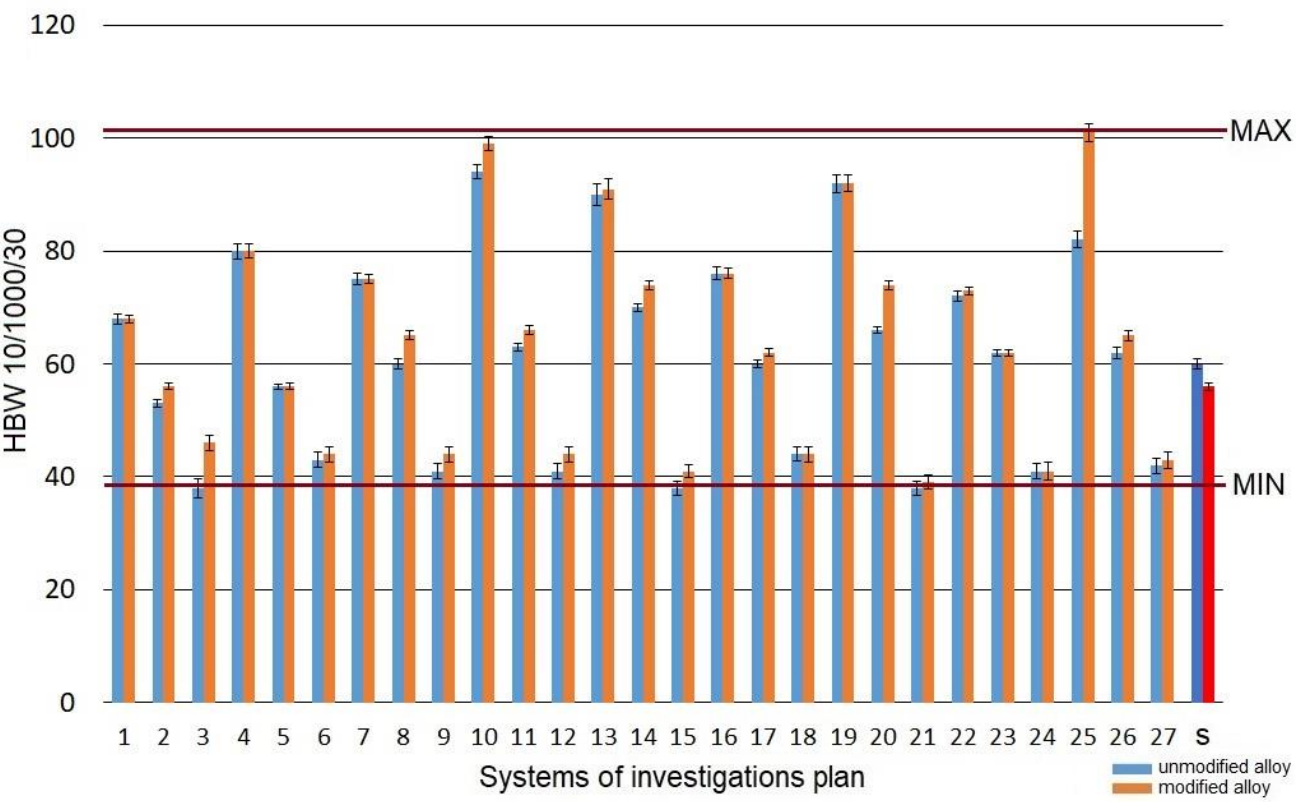

Figure 7. Hardness HBW10/1000/30 of the studied alloy: s—the initial state.

The highest increase in hardness $H B W$ was confirmed for the system marked as no. 10 $\left(t_{s}=520{ }^{\circ} \mathrm{C} ; \tau_{s}=30 \mathrm{~min} ; t_{a}=165{ }^{\circ} \mathrm{C} ; \tau_{a}=8 \mathrm{~h}\right)-99 \mathrm{HBW} 10 / 1000 / 30$ and marked as no. 25 $\left(t_{s}=550{ }^{\circ} \mathrm{C} ; \tau_{s}=30 \mathrm{~min} ; t_{a}=165^{\circ} \mathrm{C} ; \tau_{a}=8 \mathrm{~h}\right)-101 \mathrm{HBW} 10 / 1000 / 30$. The test pieces from the system no. $13\left(t_{s}=520{ }^{\circ} \mathrm{C} ; \tau_{s}=90 \mathrm{~min} ; t_{a}=165{ }^{\circ} \mathrm{C} ; \tau_{a}=5 \mathrm{~h}\right)$ and from the system no. 19 $\left(t_{s}=550{ }^{\circ} \mathrm{C} ; \tau_{s}=30 \mathrm{~min} ; t_{a}=165^{\circ} \mathrm{C} ; \tau_{a}=5 \mathrm{~h}\right)$ are characterized by a slightly lower hardness, i.e., 91-92 HBW10/1000/30. The lowest hardness was obtained for the systems nos. 6, 9, 12, 15,24 , for which the aging temperature was $325^{\circ} \mathrm{C}$ regardless of the time of this operation. The obtained hardness was at the level of 41-44 HBW10/1000/30, which denotes a significant decrease in relation to the initial alloy.

The effect of the heat treatment parameters on the change of the hardness HBW10/1000/30 of a modified alloy is presented in the form of spatial diagrams (Figure 8). The spatial diagrams were created based on the regression equation in the form of a polynomial of the second degree, which takes the form of the relation (5). The equation significance is $\alpha=0.05$.

$$
\begin{aligned}
H B W=-577.98 & +2.277 t_{s}+18.02 \cdot 10^{-4} t_{s}^{2}+17.168 \tau_{s}+1.363 \tau_{s}^{2}+0.44 t_{a} \\
& +2.39 \cdot 10^{-4} t_{a}^{2}+2.93 \tau_{a}-0.043 \tau_{a}^{2}-0.049 t_{s} \tau_{s}-13.73 \\
& \cdot 10^{-4} t_{s} t_{a}+0.008 t_{s} \tau_{a}+0.009 \tau_{s} t_{a}+0.073 \tau_{s} \tau_{a}-0.02 t_{a} \tau_{a}
\end{aligned}
$$


where: $t_{s}$-solutioning temperature, $\tau_{s}$ —solutioning time, $t_{a}$-aging temperature, $\tau_{a}$-aging time. Correlation coefficients: $\mathrm{R}^{2}=0.98$; corrr. $\mathrm{R}^{2}=0.95$.

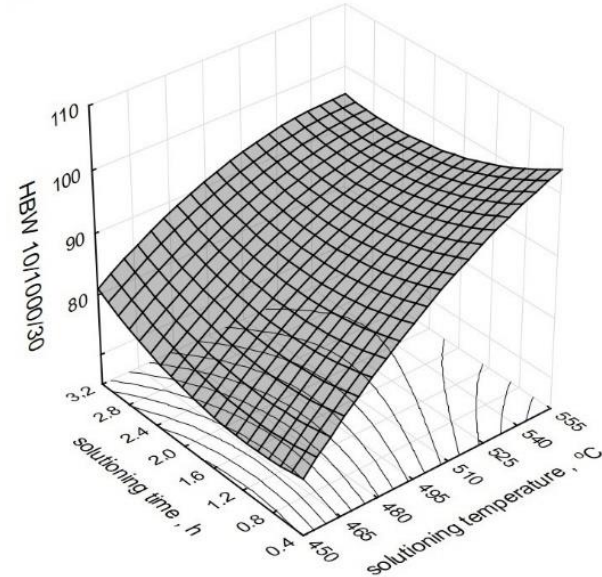

(a)

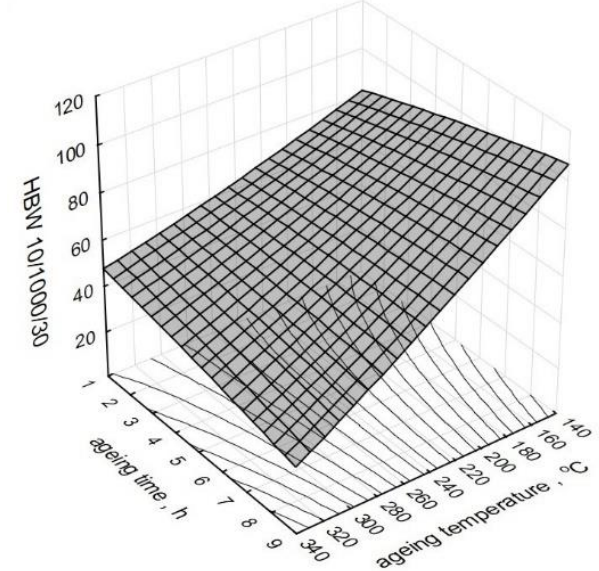

(b)

Figure 8. Effect of the heat treatment parameters on the hardness HBW10/1000/30 of the studied alloy: (a) $t_{s}$ and $\tau_{s}$, (b) $t_{a}$ and $\tau_{a}$.

For the unmodified alloy, the dependency (5) takes the form (6):

$$
\begin{aligned}
H B W=-636.31 & +2.661 t_{s}-23.01 \cdot 10^{-4} t_{s}^{2}+28.184 \tau_{s}-0.252 \tau_{s}^{2}+0.04 t \\
& +3.2 \cdot 10^{-4} t_{a}^{2}+5 \tau_{a}-0.222 \tau_{a}^{2}-0.064 t_{s} \tau_{s}-7.72 \cdot 10^{-4} t_{s} t_{a} \\
& +0.005 t_{s} \tau_{a}+0.027 \tau_{s} t_{a}-0.256 \tau_{s} \tau_{a}-0.02 t_{a} \tau_{a}
\end{aligned}
$$

Correlation coefficients: $\mathrm{R}^{2}=0.98$; corr. $\mathrm{R}^{2}=0.96$.

As constant values for the solutioning, we assumed time $\tau_{s}=1 \mathrm{~h}$ and temperature $t_{s}=520{ }^{\circ} \mathrm{C}$, while in the case of the aging: time $\tau_{a}=5 \mathrm{~h}$ and temperature $t_{a}=165{ }^{\circ} \mathrm{C}$.

Solutioning of the tested alloy in the temperature range from 525 to $540{ }^{\circ} \mathrm{C}$ for 30 to $60 \mathrm{~min}$ and aging at the temperature of $165^{\circ} \mathrm{C}$ for 5 to $8 \mathrm{~h}$ allowed to obtain the highest values of hardness $H B W 10 / 1000 / 30$ for both unmodified and modified alloy. The authors of the paper [61], after solutioning at the temperature of $540{ }^{\circ} \mathrm{C}$ for $75 \mathrm{~min}$ and aging at the temperature of $170-180^{\circ} \mathrm{C}$ for $10 \mathrm{~h}$, obtained hardness at a similar level (100 HB). By prolonging the time of solutioning to $8 \mathrm{~h}$ and aging $\mathrm{A} 356$ alloy for $6 \mathrm{~h}$ at $160{ }^{\circ} \mathrm{C}$, the authors of the study [62] obtained hardness of $118 \mathrm{HV}$ after the addition of $0.4 \% \mathrm{wt}$. of Sc. The hardness within the range of 111-116 HB was obtained by Cechini et al. [63] by solutioning A356 alloy for $4.5 \mathrm{~h}$ at the temperature of $535^{\circ} \mathrm{C}$ and artificially aging it at $160{ }^{\circ} \mathrm{C}$ for $4.5 \mathrm{~h}$. In the case of the components manufactured in the semi-solid state, to obtain hardness at the level of $125 \mathrm{HBW}$, the authors of the study [64] performed the solutioning for only $15 \mathrm{~min}$ at $540{ }^{\circ} \mathrm{C}$ and aging at $180{ }^{\circ} \mathrm{C}$ for $3 \mathrm{~h}$. The obtained values correspond to the values of the hardness obtained after $8 \mathrm{~h}$ of solutioning (conventional heat treatment according to ASTM B 917 standard). Both for modified and unmodified alloy, the obtained hardness is directly connected with the temperature of the aging. Aging at the temperatures of up to $180{ }^{\circ} \mathrm{C}$ (peak temperature) increases the hardness, while at the temperature above $200-220^{\circ} \mathrm{C}$, a decrease in the hardness can be observed as a result of over-aging the alloy [65]. The hardness is mainly controlled by the microstructure containing coherent rods or needles of $\beta^{\prime}\left(\mathrm{Mg}_{2} \mathrm{Si}\right)$. When aging at $180{ }^{\circ} \mathrm{C}$, coherent with a matrix of $\mathrm{Mg}_{2} \mathrm{Si}\left(\beta^{\prime}\right)$, needles have an impact on the increase in the hardness. Whereas, at the temperature of $220^{\circ} \mathrm{C}$, precipitation of stable, equilibrium phase $\beta\left(\mathrm{Mg}_{2} \mathrm{Si}\right)$ takes place, which is incoherent with the matrix. In such a case, the hardness tends to decrease upon the growth of the aging temperature. Thus, changes in the hardness resulting from the use of different aging temperatures in the course of heat treatment are directly correlated with $\mathrm{Mg}_{2} \mathrm{Si}$ precipitation [66]. Metastable 
intermediate fases $\beta^{\prime}$ and $\beta^{\prime \prime}$ are responsible for the hardening of the alloy, and hence, for the increase in the hardness.

\subsection{Microstructure}

The microstructure of AlSi7Mg alloy, modified and unmodified, before its heat treatment, is presented in Figure 9.

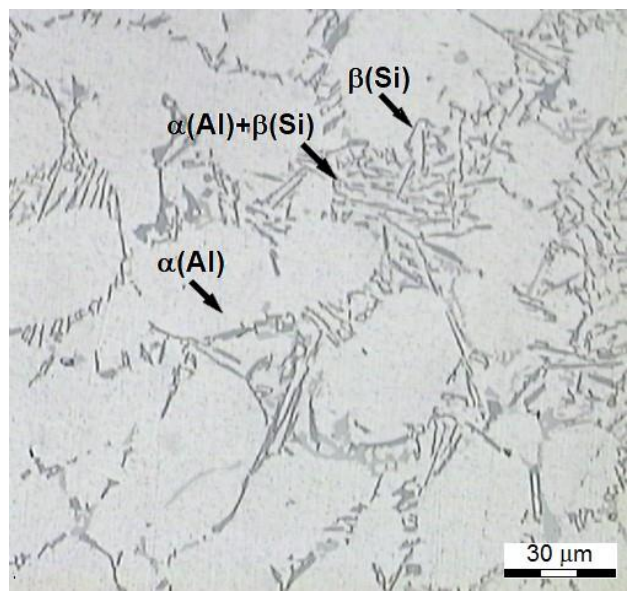

(a)

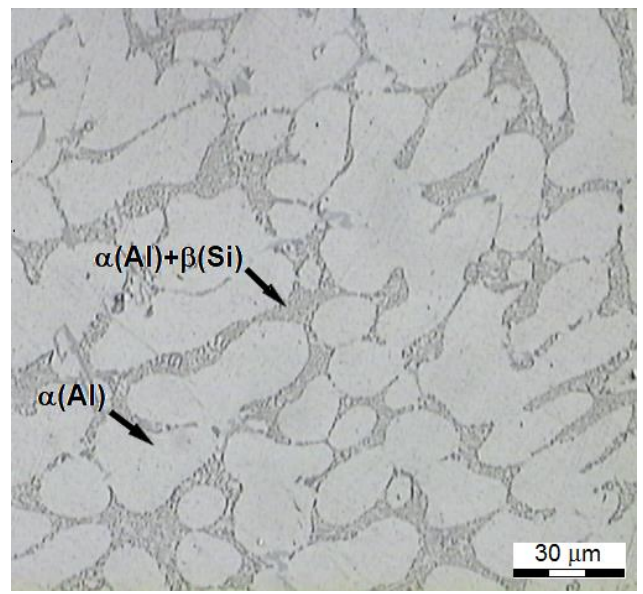

(b)

Figure 9. Microstructure of AlSi7Mg alloy in the initial state after: (a) refining, (b) refining and modification.

The refined alloy is characterized by lamellar silicon eutectics, shaped in the form of needles (Figure 9a) located within interdendric spaces, while the microstructure after the modification (Figure $9 \mathrm{~b}$ ) is characterized by a minimal interphase distance of the eutectics with fine and fibrous precipitates of $\mathrm{Si}$, and with roundings of contours of large dendrites of plastic $\alpha$-Al phase $[67,68]$. The Si precipitates visible in the photos of microstructures do not constitute separate, spherical crystals, but these are cross-sections of thin branchings of bigger eutectic Si crystals with developed dendritic or coral structures [52].

As a result of the performed heat treatment, the silicon is subjected to three successive processes: decomposition, spheroidization, and coarsening [69], and the holding time increases [70]. Microstructures (Figure 10) of the alloy featuring the highest tensile strength $R_{m}$ (system no. 25, Figure 2) have distinctive and nearly spheroidal (Figure 10b) Si precipitates within interdendric areas of phase Al. In the case of the alloy after modification, rounded corners of Si precipitates in the case of refined alloy (Figure 10a) were created after partial defragmentation of the bigger precipitates of Si. The strength and the ductility are improved by small, nearly spherical, eutectic precipitates of silicon, which are resistant to plastic deformations, and which restrict nucleation of cracks [56,70,71]. While fine eutectic particles of the silicon have a positive effect on the strength, their thickening reduces it. It is especially noticeable in the case of structures of over-aged alloy. Thus, the evolution of the eutectic silicon starts from disintegration and spheroidization of the eutectic silicon resulting from striving of the system (alloy) to minimize its free energy in given conditions by reduction of overall separation area of the phases, after which, together with the increase in time of the treatment, coarsening of the eutectic silicon, caused by the supply of $\mathrm{Si}$ atoms diffusing out of cores of dendrites, as well as by Ostwald ripening mechanism [70,72] occur. In the light of the obtained results, the form of Si precipitates does not have a significant effect on the tensile strength $R_{m}$ of heat-treated alloy. This can be confirmed by results obtained by the authors of the study [54], where the $R_{m}$ strength in case of the modified alloy after solutioning treatment at $520^{\circ} \mathrm{C}$ for $12 \mathrm{~h}$ and aging for $8 \mathrm{~h}$ at $180^{\circ} \mathrm{C}$ was higher by only $16 \mathrm{MPa}$ compared to the unmodified alloy $(215 \mathrm{MPa})$ treated in the same conditions. Wang [52], after solutioning an unmodified and a modified alloy at $540^{\circ} \mathrm{C}$ for $6 \mathrm{~h}$ and aging them at $155{ }^{\circ} \mathrm{C}$ for $4 \mathrm{~h}$, obtained a difference between them at a level of $30 \mathrm{MPa}$. A similar 
difference was obtained by Emamy [30] after solutioning at the same temperature for a twice longer time and aging for $6 \mathrm{~h}$ longer at $155^{\circ} \mathrm{C}$.

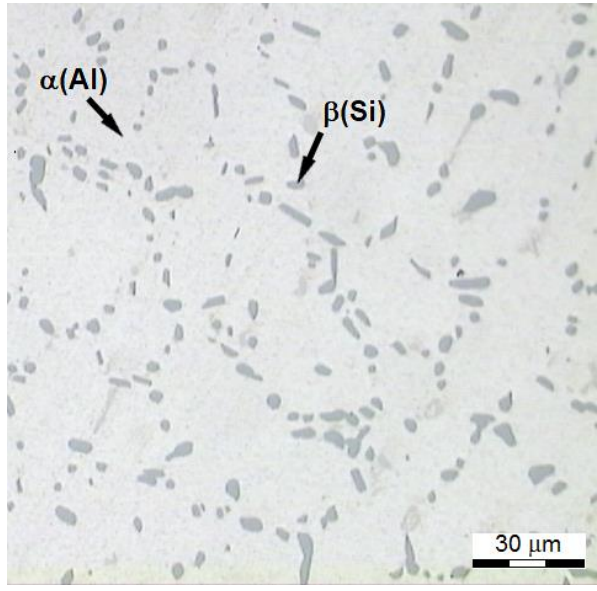

(a)

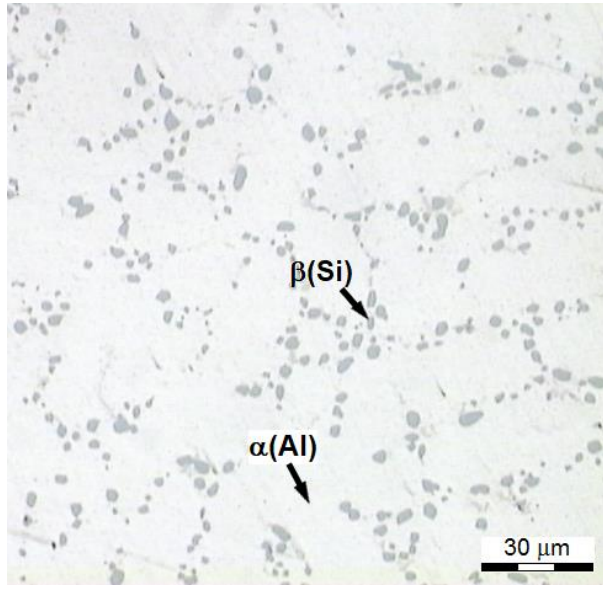

(b)

Figure 10. Microstructure of AlSi7Mg alloy is characterized by the highest strength $R_{m}$ : (a) refined alloy (328 MPa), (b) refined and modified alloy (335 MPa).

Microstructure (Figure 11) of the alloy of the test pieces having the lowest tensile strength $R_{m}$ (system no. 3-Figure 2) features extended dendrites of phase $\mathrm{Al}$ with the eutectic similar to the modified alloy, without distinct Si precipitates characteristic for heat-treated alloy. It is connected with a temperature too low compared to the temperature of conventional solutioning $\left(465^{\circ} \mathrm{C}\right)$ and the short time of this operation $(30 \mathrm{~min})$. Silicon atoms diffuse more easily at higher temperatures $\left(550{ }^{\circ} \mathrm{C}\right)$; thus, eutectic particles of the silicon may undergo a morphological transformation during a shorter time of solutioning at this temperature.

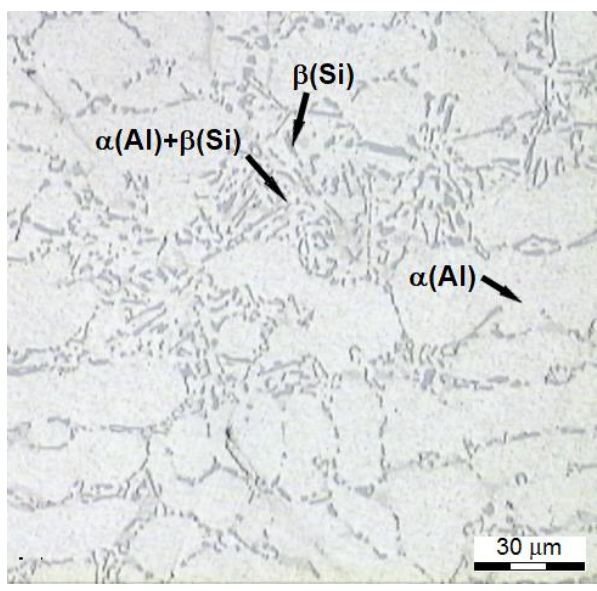

(a)

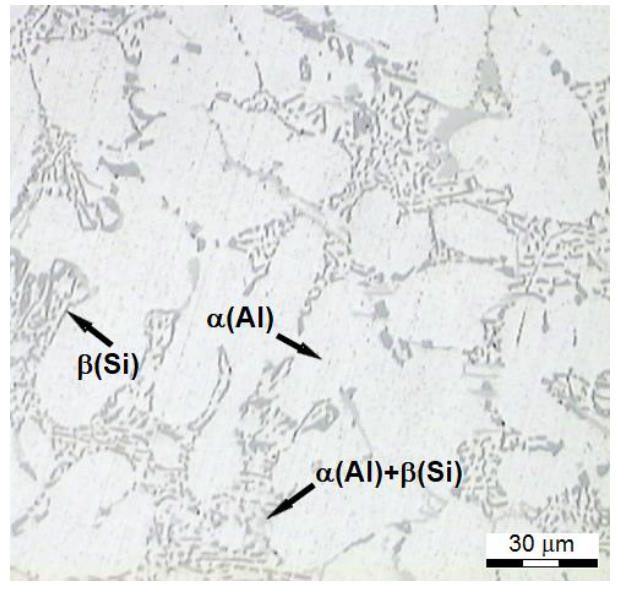

(b)

Figure 11. Microstructure of AlSi7Mg alloy, which is characterized by the lowest $R_{m}$ strength: (a) refined alloy (158 MPa), (b) modified alloy (159 MPa).

It was confirmed by Peng [50], who obtained full spheroidization of Si particles and oversaturation of $\mathrm{Si}$ and $\mathrm{Mg}$ in $\alpha-(\mathrm{Al})$ after $4 \mathrm{~h}$ of solutioning at $535^{\circ} \mathrm{C}$ for a half shorter time at the temperature of $550{ }^{\circ} \mathrm{C}$. Rometsch [59] has demonstrated that only $35 \mathrm{~min}$ of solutioning was sufficient for the complete dissolution of $\mathrm{Mg}_{2} \mathrm{Si}$ and homogenization of $\mathrm{Mg}$. Whereas, according to Zhang [49], $10 \mathrm{~min}$ of solutioning at the temperature of $540{ }^{\circ} \mathrm{C}$ or $550^{\circ} \mathrm{C}$ is sufficient to obtain the maximum level of $\mathrm{Mg}$ and $\mathrm{Si}$, which results from limiting the solubility and chemical composition of the alloy. However, prolongation of 
the treatment time to 30 min ensures spheroidization of precipitates of eutectic silicon and increases the space between these precipitates. As a result, the impact strength and ductility of the alloy, spheroidization of eutectic silicon, and dissolution of $\mathrm{Mg}_{2} \mathrm{Si}$ phase after 30 minutes of solutioning at $540{ }^{\circ} \mathrm{C}$ are improved, which is also confirmed by the study [28]. Such a short solutioning time applies to modified alloys, for which it is not necessary to dissolve branches of the silicon skeleton, characteristic of the unmodified alloy. As a result, quick spheroidization and coarsening can be obtained due to the use of shorter alloy solutioning times [56].

\section{Conclusions}

The obtained test results allowed us to evaluate ranges of solutioning and aging treatment parameters required to improve mechanical properties of AlSi7Mg alloy refined and modified with strontium.

It is possible to considerably shorten the time of the solutioning and aging, thus reducing energy consumption and improving the productivity of the process while maintaining the required mechanical properties of the AlSi7Mg alloy at the same time.

Performing modification of the AlSi7Mg alloy prior to its heat treatment does not have any significant effect on the obtained tensile strength and hardness; however, this facilitates fragmentation of silicon precipitates and their spheroidization during T6 treatment, which in turn leads to significant improvement in ductility and impact strength of the alloy.

The spatial diagrams illustrate the effect of the heat treatment parameters on selected mechanical properties (tensile strength $R_{m}$, elongation $A_{5}$, hardness $H B W$ ) obtained on the base of the assumed area of the testing.

Properly selected temperatures and times of solutioning and aging have a significant effect on the quality of the alloy; therefore, they determine the reliability of components of machinery and devices produced from the alloy to a high degree.

Obtaining tensile strength $R_{m}$ at the level of $320 \mathrm{MPa}$ and hardness of up to 100 $\mathrm{HBW} / 10 / 100 / 30$ require solutioning of the alloy for 30 to $90 \mathrm{~min}$ at the temperature of $540-550{ }^{\circ} \mathrm{C}$ followed by aging for $5-8 \mathrm{~h}$ at $165{ }^{\circ} \mathrm{C}$ (with the possibility of its shortening to 2-3 h). Whereas in the case of elongation $A_{5}$, the main parameter having an effect on its increase is an aging temperature exceeding $300^{\circ} \mathrm{C}$.

Funding: This research received no external funding.

Institutional Review Board Statement: Not applicable.

Informed Consent Statement: Not applicable.

Data Availability Statement: Data is contained within the article.

Conflicts of Interest: The author declares no conflict of interest.

\section{References}

1. Li, R.; Takata, N.; Suzuki, A.; Kobashi, M.; Okada, Y.; Furukawa, Y. Precipitation Hardening at Elevated Temperatures above $400{ }^{\circ} \mathrm{C}$ and Subsequent Natural Age Hardening of Commercial Al-Si-Cu Alloy. Materials 2021, 14, 7155. [CrossRef]

2. Ding, L.; Jia, Z.; Zhang, Z.; Sanders, R.E.; Liu, Q.; Yang, G. The natural aging and precipitation hardening behaviour of Al-Mg-Si-Cu alloys with different Mg/Si ratios and Cu additions. Mater. Sci. Eng. 2015, 627, 119-126. [CrossRef]

3. Smallman, R.E.; Ngan, A.H.W. Precipitation Hardening. In Modern Physical Metallurgy, 8th ed.; Butterworth-Heinemann: Oxford, UK, 2014; pp. 499-527.

4. Manente, A.; Timelli, G. Optimizing the Heat Treatment Process of Cast Aluminium Alloys. In Recent Trends in Processing and Degradation of Aluminium Alloys; Ahmad, Z., Ed.; InTech: Rijeka, Croatia, 2011; pp. 197-220. [CrossRef]

5. Górny, Z. Odlewnicze Stopy Metali Nieżelaznych; WNT: Warsaw, Poland, 1992; pp. 181-203.

6. Kaufman, J.G.; Rooy, E. Aluminum Alloy, Casting, Properties, Processes and Applications; ASM International: Ohio, OH, USA, 2004; pp. 27-31.

7. Tavitas-Mediano, F.J. Precipitation-hardening in cast Al-Si-Cu-Mg alloys. J. Mater. Sci. 2010, 45, 641-651. [CrossRef]

8. Sjölander, E.; Seifeddine, S. The heat treatment of Al-Si-Cu-Mg casting alloys. J. Mater. Process. Technol. 2010, 210, 1249-1259. [CrossRef] 
9. Tuncay, T. The effect of modification and grain refining on the microstructure and mechanical properties of A356 alloy. Acta Phys. Pol. 2017, 131, 89-91. [CrossRef]

10. Garat, M.; Laslaz, G.; Jacob, S.; Meyer, P.; Guerin, P.H.; Adam, R. State of the art use of Sb, Na and Sr modified Al-Si casting alloys AFS Trans. 1992, 146, 821-832.

11. Sigworth, G.K. The Modification of Al-Si Casting Alloys: Important Practical and Theoretical Aspects. Int. Met. 2008, 2, 19-40. [CrossRef]

12. Poniewierski, Z. Crystallization, Structure and Properties of Silumins; WNT: Warsaw, Poland, 1989; p. 81.

13. Faraji, M.; Todd, I.; Jones, H. Effect of Phosphorus and Strontium Additions on Formation Temperature and Nucleation Density of Primary Silicon in Al-19 Wt Pct Si Alloy and Their Effect on Eutectic Temperature. Metall. Mater. Trans. 2009, 40, 1710-1715. [CrossRef]

14. Zuo, M.; Zhao, D.; Teng, X.; Geng, H.; Zhang, Z. Effect of P and Sr complex modification on Si phase in hypereutectic Al-30Si alloys. Mater. Des. 2013, 47, 857-864. [CrossRef]

15. Qiu, C.; Miao, S.; Li, X.; Xia, X.; Ding, J.; Wang, Y.; Zhao, W. Synergistic effect of Sr and La on the microstructure and mechanical properties of A356.2 alloy. Mater. Des. 2017, 114, 563-571. [CrossRef]

16. Öztürk, I.; A ğaoğlu, G.H.; Erzi, E.; Dispinar, D.; Orhan, G. Effects of strontium addition on the microstructure and corrosion behavior of A356 aluminum alloy. J. Alloys Compd. 2018, 763, 384-391. [CrossRef]

17. Yan, P.; Mao, W.; Fan, J.; Wang, B. Simultaneous Refinement of Primary Si and Modification of Eutectic Si in A390 Alloy Assisting by Sr-Modifier and Serpentine Pouring Channel Process. Materials 2019, 12, 3109. [CrossRef]

18. Liao, H.; Sun, Y.; Sun, G. Correlation between mechanical properties and amount of dendritic $\alpha$-Al phase in as-cast near-eutectic Al-11,6\% Si alloys modified with strontium. Mater. Sci. Eng. 2002, 335, 62-66. [CrossRef]

19. Hegde, S.; Prabhu, K.N. Modification of eutectic silicon in Al-Si alloys. J. Mater. Sci. 2008, 43, 3009-3027. [CrossRef]

20. Timpel, M.; Wanderka, N.; Schlesiger, R.; Yamamoto, T.; Lazarev, N.; Isheim, D.; Schmitz, G.; Matsumura, S.; Banhart, J. The role of strontium in modifying aluminium-silicon alloys. Acta Mater. 2012, 60, 3920-3928. [CrossRef]

21. Czekaj, E.; Fajkiel, A.; Gazda, A. Short-lived ultra high temperature silicon spheroidization treatment. Arch. Foundry 2005, 5, 51-68.

22. Pezda, J. Heat treatment of EN AC-AlSi ${ }_{13} \mathrm{Cu}_{2} \mathrm{Fe}$ silumin and its effect on change of hardness of the alloy. Arch. Foundry Eng. 2011, 10, 131-134.

23. Jarco, A.; Pezda, J. Effect of Heat Treatment Process and Optimization of Its Parameters on Mechanical Properties and Microstructure of the AlSi11(Fe) Alloy. Materials 2021, 14, 2391. [CrossRef]

24. ASTM Standard B917/B917M-2001; Standard Practice for Heat Treatment of Aluminum-Alloy Castings from All Processes; ASTM International: West Conshohocken, PA, USA, 2001.

25. Kotzin, E.L. Metalcaster's Reference E Guide; American Foundrymen's Society: Des Plaines, IL, USA, 1989.

26. Roy, M.J.; Maijer, D.M. Response of A356 to warm rotary forming and subsequent T6 heat treatment. Mater. Sci. Eng. 2014, 611, 223-233. [CrossRef]

27. Morri, A. Empirical models of mechanical behaviour of Al-Si-Mg cast alloys for high performance engine applications. Metall. Sci. Technol. 2010, 28, 2-12.

28. Lu, S.P.; Du, R.; Liu, J.P.; Chen, L.C.; Wu, S.S. A new fast heat treatment process for cast A356 alloy motorcycle wheel hubs. China Foundry 2018, 15, 11-16. [CrossRef]

29. Pezda, J. Effect of Shortened Heat Treatment on the Hardness and Microstructure of 320.0 Aluminium Alloy. Arch. Foundry Eng. 2014, 14, 27-30. [CrossRef]

30. Emamy, M.; Malekan, M.; Pourmonshi, A.H.; Tavigi, K. The influence of heat treatment on the structure and tensile properties of thin-section A356 aluminum alloy casts refined by Ti, B and Zr. J. Mater. Res. 2017, 32, 3540-3547. [CrossRef]

31. Casari, D.; Ludwig, T.H.; Merlin, M.; Arnberg, L.; Garagnani, G.L. The effect of Ni and V trace elements on the mechanical properties of A356 aluminium foundry alloy in as-cast and T6 heat treated conditions. Mater. Sci. Eng. 2014, 610, 414-426. [CrossRef]

32. Zhu, M.; Jian, Z.; Yang, G.; Zhou, Y. Effects of T6 heat treatment on the microstructure, tensile properties, and fracture behavior of the modified A356 alloys. Mater. Des. 2012, 36, 243-249. [CrossRef]

33. Merlin, M.; Garagnani, G.L. Mechanical and microstructural characterisation of A356 castings realised with full and empty cores Metall. Sci. Technol. 2009, 27, 21-30.

34. Möller, H.; Govender, G.; Stumpf, W. Application of shortened heat treatment cycles on A356 automotive brake calipers with respective globular and dendritic microstructures. Trans. Nonferr. Met. Soc. China 2010, 20, 1780-1785. [CrossRef]

35. Winterbottom, W.L. Semi-solid forming applications: High volume automotive products. Metall. Sci. Technol. 2000, 18, 5-10.

36. Czekaj, E.; Zych, J.; Kwak, Z.; Garbacz-Klempka, A. Quality Index of the AlSi7Mg0.3 Aluminium Casting Alloy Depending on the Heat Treatment Parameters. Arch. Foundry Eng. 2016, 16, 25-28. [CrossRef]

37. Birol, Y. Impact of grain size on mechanical properties of AlSi7Mg0.3 alloy. Mater. Sci. Eng. 2013, 559, 394-400. [CrossRef]

38. Pisarek, B.; Rapiejko, C.; Szymczak, T.; Pacyniak, T. Effect of Alloy Additions on the Structure and Mechanical Properties of the AlSi7Mg0.3 alloy. Arch. Foundry Eng. 2017, 17, 137-142. [CrossRef]

39. Kimura, T.; Nakamoto, T. Microstructures and mechanical properties of A356 (AlSi7Mg0.3) aluminum alloy fabricated by selective laser melting. Mater. Des. 2016, 89, 1294-1301. [CrossRef] 
40. Pezda, J. Prediction of Mechanical Properties of $\mathrm{AlSi}_{13} \mathrm{Cu}_{2}$ Fe Alloy Using the ATND Methods. Mater. Res. 2016, 19, $252-257$. [CrossRef]

41. ISO 6892-1:2016; Metallic Materials-Tensile Testing, Part 1: Method of Test at Room Temperature; International Organization for Standardization: Geneva, Switzerland, July 2016.

42. ISO 6506-1:2014; Metallic Materials—Brinell Hardness Test_Part 1: Test Method, International Organization for Standardization: Geneva, Switzerland, October 2014.

43. Möller, H.; Govender, G.; Stumpf, W.E. Investigation of the T4 and T6 Heat Treatment Cycles of Semi-Solid Processed Aluminium Alloy A356. Open Mater. Sci. J. 2008, 2, 11-18. [CrossRef]

44. Azimi, H.; Nourouzi, S.; Jamaati, R. Effects of Ti particles and T6 heat treatment on the microstructure and mechanical properties of A356 alloy fabricated by compocasting. Mater. Sci. Eng. 2021, 818, 141443. [CrossRef]

45. Liu, G.; Gao, J.; Che, C.; Lu, Z.; Yi, W.; Zhang, L. Optimization of casting means and heat treatment routines for improving mechanical and corrosion resistance properties of A356-0.54Sc casting alloy. Mater. Today Commun. 2020, 24, 101227. [CrossRef]

46. Pedersen, L.; Arnberg, L. The effect of solution heat treatment and quenching rates on mechanical properties and microstructures in AlSiMg foundry alloys. Metall. Mater. Trans. 2001, 32, 525-532. [CrossRef]

47. Ragab, K.A.; Bournane, M.; Samuel, A.M.; Al-Ahmari, A.M.A.; Samuel, F.H.; Doty, H.W. Mechanical characterisation and quality index of A356-type aluminium castings heat treated using fluidised bed quenching. Mater. Sci. Technol. 2013, $29,412-425$. [CrossRef]

48. Shivkumar, S.; Ricci, S.; Steenhoff, B.; Apelian, D.; Sigworth, G. An experimental study to optimize the heat treatment of A356 alloy. AFS Trans. 1989, 97, 791-810.

49. Zhang, D.L.; Zheng, L. The Quench Sensitivity of Cast Al-7 Wt Pct Si-0.4 Wt Pct Mg Alloy. Metall. Mater. Trans. 1996, 27, 3983-3991. [CrossRef]

50. Peng, J.; Tang, X.; He, J.; Xu, D. Effect of heat treatment on microstructure and tensile properties of A356 alloys. Trans. Nonferr. Met. Soc. China 2011, 21, 1950-1956. [CrossRef]

51. Yıldırım, M.; Özyürek, D. The effects of Mg amount on the microstructure and mechanical properties of Al-Si-Mg alloys. Mater. Des. 2013, 51, 767-774. [CrossRef]

52. Wang, T.; Zheng, Y.; Chen, Z.; Zhao, Y.; Kang, H. Effects of Sr on the microstructure and mechanical properties of in situ TiB2 reinforced A356 composite. Mater. Des. 2014, 64, 185-193. [CrossRef]

53. Apelian, D.; Shivkumar, S.; Sigworth, G. Fundamental aspects of heat treatment of cast Al-Si-Mg alloys. AFS Trans. 1989, 97, 727-742.

54. Kordas, P.; Zyska, A. The effect of heat treatment on mechanical properties of squeeze castings from AlSi7Mg alloys. In Proceedings of the 26th International Conference on Metallurgy and Materials, Brno, Czech Republic, 24-26 May 2017; pp. $2694-9296$.

55. Ishak, M.; Amir, A.; Ahmad, A.H. Effect of Solution Treatment Temperature on Microstructure and Mechanical Properties of A356 Alloy. IREME 2014, 8, 289-295.

56. Zhang, D.; Zheng, L.; StJohn, D. Effect of a short solution treatment time on microstructure and mechanical properties of modified Al-7wt.\% Si-0.3 wt.\% Mg alloy. J. Light Met. 2002, 2, 27-36. [CrossRef]

57. Yan, W.; Fu, G.; Xu, Y.; Lai, W.; Chen, H. Effect of sr addition on the microstructure and properties of the A356 AL alloy. Mater. Technol. 2021, 55, 443-448. [CrossRef]

58. Ogris, E.; Wahlen, A.; Lüchinger, H.; Uggowitzer, P.J. On the silicon spheroidization in Al-Si alloys. J. Light Met. 2002, 2, 263-269. [CrossRef]

59. Rometsch, P.; Arnberg, L.; Zhang, D. Modelling dissolution of $\mathrm{Mg}_{2} \mathrm{Si}$ and homogenisation in Al-Si-Mg casting alloys. Int. J. Cast Met. Res. 1999, 12, 1-8. [CrossRef]

60. Wang, Q.G. Microstructural effects on the tensile and fracture behavior of aluminum casting alloys A356/357. Metall. Mater. Trans. 2003, 34, 2887-2899. [CrossRef]

61. Rometsch, P.A.; Schaffer, G.B. An age hardening model for Al-7Si-Mg casting alloys. Mater. Sci. Eng. 2002, 325, 424-434. [CrossRef]

62. Lim, Y.P.; Yeo, W.H.; Masita, A. Effect of heat treatment on gravity die-cast Sc-A356 aluminium alloy. Manuf. Rev. 2017, 4, 1-4. [CrossRef]

63. Ceschini, L.; Morri, A.; Morri, A.; Pivetti, G. Predictive equations of the tensile properties based on alloy hardness and microstructure for an A356 gravity die cast cylinder head. Mater. Des. 2011, 32, 1367-1375. [CrossRef]

64. Menargues, S.; Martín, E.; Baile, M.T.; Picas, J.A. New short T6 heat treatments for aluminium silicon alloys obtained by semisolid forming. Mater. Sci. Eng. 2015, 621, 236-242. [CrossRef]

65. Tash, M.; Samuel, F.H.; Mucciardi, F.; Dothy, H.W. Effect of metallurgical parameters on the hardness and microstructural characterization of as-cast and heat-treated 356 and 319 aluminum alloys. Mater. Sci. Eng. 2007, 443, 185-201. [CrossRef]

66. Sebaie, O.E.; Samuel, A.; Samuel, F.; Doty, H. The Effects of Mischmetal, Cooling Rate and Heat Treatment on the Eutectic Si Particle Characteristics of A319.1, A356.2 and A413.1 Al-Si Casting Alloys. Mater. Sci. Eng. 2008, 480, 342-355. [CrossRef]

67. Piątkowski, J.; Bińczyk, F.; Smoliński, A. The complex modification of AlSi7Mg alloy. Arch. Foundry 2004, 4, 381-386.

68. Orłowicz, W.; Mróz, M.; Tupaj, M. Effect of modification with sodium or strontium on microstructure and mechanical properties of AlSi7Mg alloy. Arch. Foundry 2006, 6, 381-386. 
69. Lados, D.A.; Apelian, D.; Wang, L.B. Solution treatment effects on microstructure and mechanical properties of Al-(1 to 13 pct) $\mathrm{Si}-\mathrm{Mg}$ cast alloys. Metall. Mater. Trans. 2003, 42, 171-180. [CrossRef]

70. Ogris, E. Development of Al-Si-Mg Alloys for Semi-Solid Processing and Silicon Spheroidization Treatment (SST) for Al-Si Cast Alloys. Ph.D. Thesis, Swiss Federal Institute of Technology Zurich, Zürich, Switzerland, 2002.

71. Caceres, C.H.; Wang, Q.G. Solidification conditions, heat treatment and the tensile ductility of Al-7Si-0.4Mg casting alloys. AFS Trans. 1996, 104, 1039-1043.

72. Tiryakioglu, M. Si particle size and aspect ratio distributions in an $\mathrm{Al}-7 \% \mathrm{Si}-0.6 \% \mathrm{Mg}$ alloy during solution treatment. Mater. Sci. Eng. 2008, 473, 1-6. [CrossRef] 